\section{Biological Sciences}

MOSCONA, A.A. and MONROY, A. (eds). Genome Function, Cell Interactions, and Differentiation. Current Topics in Developmental Biology, Vol.18. Pp.227. ISBN 0-12-153118-X. (Academic: 1983.) \$32.

MOUNT, M.S, and LACY, G.H. (eds) Phytopathogenic Prokaryotes, Vol.1. Pp.541. ISBN 0-12-509001-3. (Academic: 1982.) \$59.50.

MOUNT, M.S. and LACY, G.H. (eds). Phytopathogenic Prokaryotes, Vol.2. Pp.506. ISBN 0-12-509002-1. (Academic: 1982.) \$57.

MROSOVSKY, N. Conserving Sea Turtles. Pp.176. Pbk ISBN 0-9507371-1-9. (British Herpetological Society: 1983.) £S, \$10.

MULCAHY, D.L. and OTTAVIANO, E. (eds). Pollen: Biology and Implications for Plant Breeding. Proceedings of a Symposium held June 1982, Italy. Pp.446. ISBN 0-444-00738-5. (Elsevier Biomedical/ North Holland: 1983.) $\$ 70$.

MULLER, A. and NEWTON, W.E. (eds). Nitrogen Fixation: The Chemical-Biochemical-Genetic Interface. Pp.379. ISBN 0-306-41258-6. (Plenum: 1983.) Np.

NEMEROFF, C.B. and PRANGE, A.J. Jr. (eds) Neurotensin, A Brain and Gastrointestinal Peptide. Annals of the New York Academy of Sciences, Vol.400. Hbk ISBN 0-89766-19-7; pbk ISBN 0-89766-191-5. (New York Academy of Sciences: 1982.) Hbk np; pbk $\$ 80$.

NOWOTNY, A. (ed.). Pathological Membranes. Biomembranes, Vol.11. Pp.473. ISBN 0-306-41065-6. (Plenum: 1983.) Np.

ORTONNE, J-P, MOSHER, D.B. and FITZPATRICK, T.B. Vitiligo and Other Hypomelanoses of Hair and Skin. Pp.683. ISBN 0-306-40974-7. (Plenum: 1983.) \$79.50.

OSTERBERG, R. (ed.). Inorganic Biochemistry. Proceedings of the 56th Nobel Symposium held September 1982, Sweden. Pp.160. No ISBN. (The Royal Swedish Academy of Sciences: 1983.) Np.

PALMER, E. A Field Guide to the Trees of Southern Africa, 2nd Edn. Pp.393. ISBN 0-620-05468-9. (Collins: 1983.) £8.95

PAPAGEORGIOU, G.C. and PACKER, L. (eds). Photosynthetic Prokaryotes: Cell Differentiation and Function. Proceedings of the Special FEBS Meeting held April 1982, Greece. Pp.407. ISBN 0-444-00732-6. (Elsevier Biomedical/North Holland: 1983.) \$65.

PARTHIER, B. and BOULTER, D. (eds). Nucleic Acids and Proteins in Plants II: Structure, Biochemistry and Physiology of Nucleic Acids. Encyclopedia of Plant Physiology, New Series, Vol.14. Part B. Pp.774. ISBN 3-540-11140-9/0-387-11140-9. (Springer-Verlag: 1982.) DM 268, \$107.20.

PEARSON, M.L and EPSTEIN, H.F. (eds) Muscle Development: Molecular and Cellular Control. Pp.572. ISBN 0-87969-154-9. (Cold Spring Harbor: 1983.) \$57, \$68.40 (elsewhere)

PICK, H.L. Jr. and ACREDOLO, L.P. (eds) Spatial Orientation: Theory, Research, and Application. Pp.378. ISBN 0-306-41255-1. (Plenum: 1983.) Np.

PIERCE, C.W. et al. (eds). Ir Genes: Past, Present, and Future. Pp.621. ISBN 0-89603-050-4. (Humana Press: 1983.) \$64.50 (US), \$74.50 (elsewhere).

SMITH, J.E. and LANE, J.D. (ed.). The Neurobiology of Opiate Reward Processes. Pp.475. ISBN 0-444-80430-7. (Elsevier Biomedical/North Holland: 1983.) \$144.75, Dfl. 340

SOTO, R.J., SARTORIO, G. and de FORTEZA, I (eds). New Concepts in Thyroid Disease. Proceedings of the International Symposium held October 1981, Argentina. Pp.250. ISBN 0-8451-0116-1. (Alan R. Liss: 1983.) $£ 20$.

SOUTH, G.R. (ed.). Biogeography and Ecology of the Island of Newfoundland. Monographiae Biologicae, Vol. 48. Pp.736. ISBN 90-6193-101-0. (Dr. W. Junk: 1983.) Dfl. 300, $\$ 130$

STEYN, P. Birds of Prey of Southern Africa: Their Identification and Life Histories. Pp.309. ISBN 0-908396-64-3/0-7099-2382-1. (David Philip/Croom Helm: 1983.) £29.50.
STONE, A.R., PLATT, H.M. and KHALIL, L.F. (eds). Concepts in Nematode Systematics. The Systematics Association Special Volume No. 22 Pp.400. ISBN 0-12-672680-9. (Academic: 1983.) £28, $\$ 50$.

SUBRAMANIAN, C.V. Hyphomycetes: Taxonomy and Biology. Pp.502. ISBN 0-12-675620-1. (Academic: 1982.) £35, \$65.

THE CIBA FOUNDATION. Brush Border Membranes. Ciba Foundation Symposium 95. Pp.340. ISBN 0-272-79659-X. (Pitman: 1983.) £25, \$35.

VAN TIENHOVE, A. Reproductive Physiology of Vertebrates, 2nd Edn. Pp.491. ISBN 0-8014-128-1. (Cornell University Press: 1983.) f42, \$64.35.

VOLPE, E.P. Biology and Human Concerns, 3rd Edn. Pp.675. ISBN 0-697-04734-2. (Wm. C. Brown: 1983.) Np.

WACHTEL, S.S. H-Y Antigen and The Biology of Sex Determination. Pp.302. ISBN 0-8089-1514-2. (Grune \& Stratton: 1983.) \$44.

WATERHOUSE, J. et al. (eds). Cancer Incidence in Five Continents, Vol. 4. Pp.812. ISBN 92-8-321142-1. (IARC: 1982.) SwFr. 100, \$50.

WEISS, D.G. and GORIO, A. (eds). Axonplasmic Transport in Physiology and Pathology. Pp.192. ISBN 3-540-11663-X/0-387-11663-X. (Springer-Verlag: 1982.) DM 78, $\$ 31.20$.

WENG, H.T. Fishes in Varied Reproduction and Sexuality. Pp.60. Pbk ISBN 0-949711-00-4. (Fishing Weng, Australia: 1982.) Np.

YAMAMDA, K.M. (ed.). Cell Interactions and Development: Molecular Mechanisms. Pp.287. ISBN 0-471-07987-1. (Wiley: 1983.) £33, \$53.

YOSHIDA, $T$, and TORISU, $M$. (eds). Immunobiology of the Eosinophil. Proceedings of the 1st International Symposium held November 1981, Japan. Pp.399. ISBN 0-444-00761-X. (Elsevier Biomedical/North Holland: 1983.) \$75, Dfl. 205.

ZRENNER, E. Neurophysiological Aspects of Color Vision in Primates: Comparative Studies on Simian Retinal Ganglion Cells and the Human Visual System. Pp.218. ISBN 3-540-11653-2/0-387-11653-2. (SpringerVerlag: 1983.) DM 89, $\$ 35.60$.

ZUBAY, G, Biochemistry, Pp.1268, ISBN 0-201-09091-0. (Addison-Wesley: 1983.) £16.95.

\section{History of Science}

LLOYD, G.E.R. Science, Folklore and Ideology: Studies in the Life Sciences in Ancient Greece. Pp.260. Hbk ISBN 0-521-25314-4; pbk ISBN 0-521-27307-2. Cambridge University Press: 1983.) Hbk £25, \$49.50; pbk £8.95, \$16.95.

RONAN, C.A. The Cambridge Illustrated History of the World's Science. Pp.543. ISBN 0-600-38423-3/ 0-521-25844-8. (Newnes/Cambridge University Press: 1983.) $\mathrm{f} 12.95$.

W.ESTFALL, R.S. Never at Rest: A Biography of Isaac Newton. Pp.908. Hbk ISBN 0-521-23143-4; pbk ISBN 0-521-27435-4. (Cambridge University Press: 1983.) Hbk np; pbk $£ 12.50$.

\section{General}

FIRT, V. Statics, Formfinding and Dynamics of AirSupported Membrane Structures. Pp.449. ISBN 90-247-2672-7. (Martinus Nijhoff: 1983.) Dfl. 190, \$83.

FOELL, W.K. and HERVEY, L.A. (eds). National Perspectives on Management of Energy/Environment Systems. International Series on Applied Systems Analysis, Vol. 11. Pp.343. ISBN0-471-10022-6. (Wiley: 1983.) £32, \$59.95

FOWLER, P.J. The Farming of Prehistoric Britain Pp.246. Pbk ISBN 0-521-27369-2. (Cambridge University Press: 1983.) £7.50, \$14.95.

GOLDSTEIN, G. and RUTHVEN, L. Rehabilitation of the Brain-Damaged Adult. Pp.362. ISBN 0-306-40498-2. (Plenum: 1983.) \$27.50.

GOTTFRIED, R.S. The Black Death: Natural and Human Disaster in Medieval Europe. Pp.194. ISBN 0-02-912630-4. (Collier Macmillan: 1983.) \$16.95.
HARRIS, C.J. and VALENCA, J.M.E. The Stability of Input-Output Dynamical Systems. Pp.280. ISBN 0-12-327680-2. (Academic: 1983.) £27.20, \$45

HERRMANN, A.G. Radioactive Abfalle: Probleme und Verantwortung. Pp.256. Pbk ISBN 3-540-12028-9/0-387-12028-9. (Springer-Verlag: 1983.) DM 18, \$7.20.

HUBBARD, L.R. The Problems of Work: How to Solve Them and Succeed. Pp.179. Hbk ISBN 87-7336210-7/0-88404-133-6; pbk ISBN 87-7336-121-3/ 0-88404-132-8. (New Era/Bridge Publications: 1983.) Np.

HUNT, M. The Universe Within: A New Science Explores The Human Mind. Pp.415. Hbk ISBN 0-671-25258-5; pbk ISBN 0-671-25259-3. (Simon \& Schuster: 1983.) Hbk np; pbk \$9.95.

JENNINGS, J.D (ed.). Ancient North Americans. Pp.642. ISBN 0-7167-1428-0. (W.H. Freeman: 1983.) $£ 20.95$.

JENSEN, J. The Prehistory of Denmark. Pp.331. Hbk ISBN 0-416-34190-X; pbk ISBN 0-416-34200-0. (Methuen: 1982.) Hbk £14.95; pbk £8.95.

KINGHORN, R.R.F. An Introduction to the Physics and Chemistry of Petroleum. Pp.420. ISBN 0-471-90054-0. (Wiley: 1983.) £19.50, \$36.50.

KRASILSHCHIKOVA, E.A. A Thin Wing in a Compressible Flow. Pp.247. ISBN 0-306-10972-7. (Plenum: 1983.) \$45.

LEHMAN, J.P. (ed.). Hazardous Waste Disposal. NATO Challenges of Modern Society, Vol. 4. Pp.396. ISBN 0-306-41171-7. (Plenum: 1983.) \$49.50.

LONGACRE, R.E. The Grammar of Discourse. Pp.423. ISBN 0-306-41273-X. (Plenum: 1983.) S45.

MACLEAN, C. Island on the Edge of the World. The Story of St. Kilda. Pp.160. Pbk ISBN 0-86241-045-2. (Canongate: 1983.) £3.50.

MARSH, G. The Local Plan Inquiry: Its Role in Local Plan Preparation. Pp.167. Pbk ISBN 0-08-030442-7. (Pergamon: 1983.) £11, \$20.

McCONNELL, R.B. (ed.). Art, Science and Human Progress. Pp.196. ISBN 0-7195-4018-6. (John Murray: 1983.) £12.50.

MILLER, G. Keepers of the Kingdom. Pp.447. ISBN 0-340-28128-6. (Hodder \& Stoughton: 1983.) C8.95.

MITCHELL, R.J. Earth Structures Engineering. Pp.265. Hbk ISBN 0-04-624003-9; pbk ISBN 0-04-624004-7. (George Allen \& Unwin: 1983.) Hbk $£ 20$; pbk $£ 11.95$.

MOSSAKOWSKI, D. and ROTH, G. (eds). Environmental Adaptation and Evolution: A Theor etical and Empirical Approach. Pp.302. Pbk ISBN 3-437-30422-4/0-89574-181-4. (Gustav Fischer Verlag: 1982.) DM 68

MUJUMDAR, A.S. (ed.). Advances in Drying, Vol. 2. Pp.301. ISBN 0-89116-255-0. (Hemisphere: 1983.) $\$ 55$

OLSON, R. Science Deified and Science Defied: The Historical Significance of Science in Western Culture. Pp.329. ISBN 0-520-04621-8. (University of California Press: 1983.) $£ 27.50, \$ 42$

PATTERSON, I. The British Veterinary Profession 1791-1948. Pp.207. ISBN 0-85131-379-5. (J.A. Allen: 1983.) $£ 9.50$.

PFEFFER, R (ed,). Fourth International Conference on Physicochemical Hydrodynamics. pp.535. Hbk ISBN 0-89766-200-8; pbk ISBN 0-89766-201-6. (New York Academy of Sciences: 1983.) Hbk np; pbk $\$ 100$.

PIGGOTT, S. The Earliest Wheeled Transport: From the Atlantic Coast to the Caspian Sea. Pp.272. ISBN 0-500-01279-2. (Thames \& Hudson: 1983.) '£20.

PRICE, B. Friends of the Earth Guide to Pollution. Pp.96. Pbk ISBN 0-85117-235-0. (Maurice Temple Smith: 1983.) f1.95.

RILEY, F.L. (ed.). Progress in Nitrogen Ceramics. NATO Advanced Science Institute Series E: Applied Sciences. Pp.814. ISBN 90-247-2828-2. (Martinus Nijhoff: 1983.) Dfl. 230, $\$ 100$.

ROHMERT, W, and LANDAU, K. A New Technique for Job Analysis. Pp.93. Pbk ISBN 0-85066-251-6. (Taylor \& Francis: 1983.) £9.50.

RUEDISILI, L.C. and FIREBAUGH, M.W. (eds). Perspectives on Energy, 3rd Edn: Issues, Ideas, and Environmental Dilemmas. Pp.605. Hbk ISBN 0-19-503289-6; pbk ISBN 0-19-503038-9. (Oxford University Press: 1983 .) Hbk np; pbk $£ 9.95$. 